\title{
Usefulness of mid-week hemoglobin measurement for anemia management in patients undergoing hemodialysis: a retrospective cohort study
}

Soo Ya Bae ${ }^{1}$, Jae Wan Jeon ${ }^{2}$, Seong Hoon Kim³ ${ }^{3}$ Chung Hee Baek ${ }^{4}$, Jai Won Jang ${ }^{4}$, Won Seok Yang ${ }^{4}$, Soon Bae Kim ${ }^{4}$, Su-Kil Park ${ }^{4}$, Sang Koo Lee ${ }^{4}$ and Hyosang Kim ${ }^{4^{*}}$ (i)

\begin{abstract}
Background: Short-term hemoglobin $(\mathrm{Hb})$ variability related to volume status is observed in chronic kidney disease (CKD) patients receiving hemodialysis (HD). Given the lack of studies regarding outcomes according to the day of $\mathrm{Hb}$ sampling, the existing guidelines do not strongly recommend regarding measurement timing. Pre-dialysis midweek sampling (Wednesday and Thursday) is preferable to minimize short-term Hb variability, although numerous HD centers perform early-week sampling (Monday and Tuesday). The different measurement days may influence the prescribed dose of erythropoiesis-stimulating agent (ESA) and related patient outcomes. We investigated changes in $\mathrm{Hb}$ levels and ESA doses according to the $\mathrm{Hb}$ measurement day among HD patients.

Methods: Starting September 2013, the day for pre-dialysis Hb measurement at the Asan Medical Center was changed from early-week days to mid-week days. This single-center retrospective study evaluated medical records of 92 patients who received maintenance HD between September 2012 and August 2014.

Results: There was no significant difference in the mean $\mathrm{Hb}$ levels between early-week days and mid-week days $(10.71 \pm 0.06 \mathrm{~g} / \mathrm{dL}$ vs. $10.78 \pm 0.47 \mathrm{~g} / \mathrm{dL}, p=0.105)$. However, the mean doses of darbepoetin-a on early-week days were higher than those on mid-week days $(175.4 \pm 72.5 \mu \mathrm{g} / \mathrm{month}$ vs. $163.7 \pm 83.6 \mu \mathrm{g} / \mathrm{month}, p=0.022)$. The mean doses of intravenous iron hydroxide sucrose for early-week measurements were also higher than those for midweek measurements $(623.0 \pm 489.0 \mathrm{mg} /$ year vs. $447.0 \pm 505.2 \mathrm{mg} / \mathrm{year}, p=0.001)$. The mean interdialytic weight gains were $2.81 \pm 0.82 \mathrm{~kg}$ on early-week days and $1.99 \pm 0.61 \mathrm{~kg}$ on mid-week days $(p<0.001)$.
\end{abstract}

Conclusions: Compared with early-week measurements, mid-week pre-dialysis $\mathrm{Hb}$ measurements were significantly associated with lower ESA doses without a change in Hb levels.

Keywords: Hemoglobin, Anemia, Chronic kidney disease, Hemodialysis, Erythropoiesis-stimulating agent

\section{Background}

Anemia is a common feature of chronic kidney disease (CKD) and is related to poor outcomes, such as reduced quality of life, cardiovascular disease, and mortality [1]. Anemia in CKD patients is a multifactorial process associated with a relative erythropoietin (EPO) deficiency,

\footnotetext{
*Correspondence: mateus@amc.seoul.kr

${ }^{4}$ Division of Nephrology, Department of Internal Medicine, Asan Medical Center, University of Ulsan College of Medicine, 88, Olympic-ro 43-gil, Songpa-gu, Seoul 05505, Republic of Korea

Full list of author information is available at the end of the article
}

uremic-induced inhibition of erythropoiesis, shortened erythrocyte survival, and disordered iron homeostasis [2]. The introduction of recombinant human EPO (rhEPO) and erythropoiesis-stimulating agents (ESAs) has helped limit anemia-related symptoms and reduce the need for repeated blood transfusions. However, ESA treatment has various adverse effects such as hypertension, seizure, and vascular access clotting [3, 4]. Recent randomized controlled trials have also indicated that correction of hemoglobin $(\mathrm{Hb})$ levels to near the normal range was associated with increased risks of mortality,

(c) The Author(s). 2019 Open Access This article is distributed under the terms of the Creative Commons Attribution 4.0 International License (http://creativecommons.org/licenses/by/4.0/), which permits unrestricted use, distribution, and reproduction in any medium, provided you give appropriate credit to the original author(s) and the source, provide a link to the Creative Commons license, and indicate if changes were made. The Creative Commons Public Domain Dedication waiver (http://creativecommons.org/publicdomain/zero/1.0/) applies to the data made available in this article, unless otherwise stated. 
cardiovascular events, and stroke [5-12]. Secondary analysis of trial data also indicated that higher doses of ESA or ESA hypo-responsiveness were related to poor outcomes [11-16]. Therefore, the National Kidney Foundation Kidney Disease Outcomes Quality Initiative (KDOQI) guidelines recommend targeting $\mathrm{Hb}$ levels of $11.0-12.0 \mathrm{~g} / \mathrm{dL}$ and not greater than $13.0 \mathrm{~g} / \mathrm{dL}$ in CKD patients receiving dialysis or ESA therapy without dialysis [17]. The Kidney Disease Improving Global Outcomes (KDIGO) guidelines recommend judicious and individualized ESA therapy, although ESA treatment is generally not used to maintain an $\mathrm{Hb}$ level of $>11.5 \mathrm{~g} / \mathrm{dL}$ [18].

The fluctuation in measured $\mathrm{Hb}$ levels in CKD patients ( $\mathrm{Hb}$ variability) can be related to ESA therapy, iron status, and other CKD-related and -unrelated comorbid conditions [19, 20]. For example, hydration status significantly influences the short-term $\mathrm{Hb}$ variability, especially in patients with end-stage renal disease (ESRD) receiving hemodialysis (HD) [21-23]. Thus, there have been several discussions regarding determining a representative $\mathrm{Hb}$ value in ESRD patients, although these discussions have failed to produce a definitive conclusion [24-26]. Furthermore, the published guidelines for anemia do not firmly recommend regarding the timing of $\mathrm{Hb}$ measurement in ESRD patients receiving $\mathrm{HD}$, given the lack of studies regarding patient outcomes according to the $\mathrm{Hb}$ measurement day [18, 27, 28]. Nevertheless, it is important to select optimal ESA dosing based on representative $\mathrm{Hb}$ levels and appropriate targets because unnecessarily low or high ESA doses are associated with poor outcomes. Therefore, we investigated the changes in $\mathrm{Hb}$ levels and ESA doses according to the $\mathrm{Hb}$ measurement day among ESRD patients receiving maintenance $\mathrm{HD}$.

\section{Methods}

\section{Study population}

Starting September 2013, pre-dialysis Hb measurements were changed from early-week days (Monday or Tuesday, days after a long interdialytic period) to mid-week days (Wednesday or Thursday, days after a short interdialytic period) at the HD unit in Asan Medical Center (AMC), Seoul, South Korea. This single-center retrospective study evaluated medical records of patients receiving maintenance HD at the AMC HD unit between September 2012 and August 2014. Patients had conventional HD for four hours a day, three times a week. For patients who had dialysis for over five years, we used high flux membranes. There was no use of convective treatments nor high cutoff membranes. A total of 120 patients were identified who had anemia, were $>20$ years old, were receiving maintenance HD for $\geq 3$ months, and continued treatment at the AMC HD unit during the 2- year study period. Eight patients with massive bleeding events that required transfusions, 11 who underwent a major operation with considerable bleeding risk, 1 with an untreated gastrointestinal tract malignancy, 1 with a cytopenia event caused by treatment for chronic hepatitis C, 1 who was hospitalized for $>2$ months, 3 with preexisting non-anemia hematological disorders, 2 who refused ESA treatment because of poor compliance, and 1 with a formal do-not-resuscitate order were excluded. Thus, the present study included 92 patients. The study protocol was approved by the institutional review board of AMC. Informed consent was not required, given the retrospective observational study design.

\section{Measurements}

The baseline clinical characteristics of interest were age, sex, cause of ESRD, medical history, surgical history, and medication history. The laboratory parameters of interest were $\mathrm{Hb}$, hematocrit, dialysis adequacy, albumin, prealbumin, high-sensitivity C-reactive protein, intact parathyroid hormone, ferritin, and transferrin saturation. These parameters were usually measured once a month except for prealbumin, dialysis adequacy, high-sensitive C-reactive protein, intact parathyroid hormone which were checked every 3 months. When $\mathrm{Hb}$ and $\mathrm{Hct}$ checked more than once a month for some reasons other than the exclusion criterion, we used the average value of them. The doses of ESAs and intravenous (IV) iron were also reviewed. The parameters of interest of the volume status were interdialytic body weight gain, ultrafiltration volume, and pre-dialysis body weight/dry body weight on the $\mathrm{Hb}$ measurement day. The ESAs used for patients were rhEPO- $\alpha$ (Epokine ${ }^{\circ}$ in a prefilled syringe; CJ HealthCare, Seoul, South Korea) and darbepoetin- $\alpha$ (Nesp $^{\circ}$ in a prefilled syringe; Kyowa Hakko Kirin Co., Ltd., Tokyo, Japan). The weekly dose of rhEPO- $\alpha$ was divided by 200 to convert it into the corresponding weekly dose of darbepoetin- $\alpha$. 200:1 is a conventional ratio used when weekly dose of rhEPO- $\alpha$ is converted to darbepoetin- $\alpha$ [29]. The IV iron was administered as Venoferrum ${ }^{\bullet}$ (JW Pharmaceutical Inc., Seoul, Korea), which contains ferric hydroxide sucrose complex $(2700 \mathrm{mg})$ and $\mathrm{Fe}^{3+}(100 \mathrm{mg})$ in a single ampoule.

\section{Statistical analysis}

The paired values from the early-week and mid-week measurements were compared. By Kolmogorov-Smirnov test, $\mathrm{Hb}$, dose of ESA, ultrafiltration volume, $\mathrm{Kt} / \mathrm{V}$, prealbumin, iPTH were normally distributed. Parametric continuous variables were analyzed using the paired test, and were reported as mean \pm standard deviation or median (range or interquartile range), as appropriate. Nonparametric continuous variables were analyzed using 
Wilcoxon signed rank test. Differences in the numbers of patients who achieved the target $\mathrm{Hb}$ levels were evaluated using Pearson's chi-square test and Fisher's exact test. Differences in the ESA doses according to the achievement of the targeted $\mathrm{Hb}$ levels were evaluated using the Kruskal-Wallis test. All analyses were performed using IBM SPSS software (version 20; IBM Corp., Armonk, NY), and differences were considered statistically significant at $p$-values of $<0.05$.

\section{Results}

Table 1 shows the patients' baseline characteristics. The mean age was 61.6 years, and diabetes mellitus was the leading cause of ESRD (50.0\%). At baseline, some patients had histories of cardiovascular disease (23.9\%), cerebrovascular accident (17.4\%), malignancy (18.5\%), kidney transplantation (9.8\%), and other solid organ transplantation (3.3\%). Most of the patients were receiving anti-hypertensive agents (93.5\%) and antiplatelet agents $(81.5 \%)$, while only a small proportion were receiving anticoagulant agents (4.3\%).

Table 2 shows the Hb levels, ESA doses, and parameters related to volume status and anemia according to the $\mathrm{Hb}$ measurement days. There was no significant difference in the mean $\mathrm{Hb}$ levels between the early-week and mid-week measurements $(10.71 \pm 0.06 \mathrm{~g} / \mathrm{dL}$ vs. $10.78 \pm 0.47$ $\mathrm{g} / \mathrm{dL}, p=0.105$ ) (Fig. 1). However, the mean dose of darbepoetin- $\alpha$ alfa was significantly higher for early-week days than for mid-week days $(175.4 \pm 72.5 \mu \mathrm{g} /$ month vs. $163.7 \pm 83.6 \mu \mathrm{g} /$ month, $p=0.022$ ) (Fig. 2). Furthermore, the mean IV dose of iron hydroxide sucrose was higher for early-week days than for mid-week days $(623.0 \pm 489.0 \mathrm{mg} /$ year vs. $447.0 \pm 505.2 \mathrm{mg} /$ year, $p=0.001$ ).

There was a significant difference in the mean interdialytic weight gains between the early-week and midweek measurements $(2.81 \pm 0.82 \mathrm{~kg}$ vs. $1.99 \pm 0.61 \mathrm{~kg}$, $p<0.001$ ) (Fig. 3). There was also a significant difference in the ultrafiltration volumes between the early-week and mid-week measurements $(2.65 \pm 0.73 \mathrm{~kg}$ vs. $2.12 \pm$ $0.66 \mathrm{~kg}, p<0.001)$. Furthermore, there was a significant difference in the ratios of pre-dialysis body weight/dry body weight between the early-week and mid-week measurements $(104.89 \pm 3.42$ vs. $103.51 \pm 1.77, p<0.001)$.

Dialysis adequacy was appropriate in both groups, and there were no significant differences between the two groups in terms of high-sensitivity $\mathrm{C}$-reactive protein or transferrin saturation. However, a significant difference in ferritin levels was detected $(p<0.001)$. A significant difference in intact parathyroid hormone levels was also detected $(p=0.021)$, although both levels were within the target range.

Table 3 shows the doses of ESA according to the $\mathrm{Hb}$ levels. There was no clinically significant change in the number of patients after changing the $\mathrm{Hb}$
Table 1 Baseline characteristics

\begin{tabular}{|c|c|}
\hline & Values \\
\hline Age (years) & $61.6 \pm 12.1$ \\
\hline \multicolumn{2}{|l|}{ Sex } \\
\hline Male & $46(50.0 \%)$ \\
\hline Duration of HD (years) & $8.3 \pm 4.9$ \\
\hline \multicolumn{2}{|l|}{ Cause of ESRD } \\
\hline DM & $46(50.0 \%)$ \\
\hline HTN & $21(22.8 \%)$ \\
\hline Primary GN & $8(8.7 \%)$ \\
\hline ADPKD & $2(2.2 \%)$ \\
\hline Others & $8(8.7 \%)$ \\
\hline Unknown & $5(5.4 \%)$ \\
\hline \multicolumn{2}{|l|}{ Medical history } \\
\hline DM & $46(50.0 \%)$ \\
\hline HTN & $86(93.5 \%)$ \\
\hline CVD & $22(23.9 \%)$ \\
\hline CHF & $12(13.0 \%)$ \\
\hline VHD & $7(7.6 \%)$ \\
\hline CAOD & $11(12.0 \%)$ \\
\hline PAOD & $4(4.3 \%)$ \\
\hline Arrhythmia & $6(6.5 \%)$ \\
\hline CVA & $16(17.4 \%)$ \\
\hline Bleeding ${ }^{a}$ & $10(10.9 \%)$ \\
\hline Chronic liver disease & $9(9.8 \%)$ \\
\hline Malignancy & $17(18.5 \%)$ \\
\hline Thyroid illness & $8(8.7 \%)$ \\
\hline \multicolumn{2}{|l|}{ Medication history } \\
\hline Antiplatelet agents & $75(81.5 \%)$ \\
\hline Anticoagulants & $4(4.3 \%)$ \\
\hline Antihypertensive agents & $86(93.5 \%)$ \\
\hline Thyroid hormones & $5(5.4 \%)$ \\
\hline \multicolumn{2}{|l|}{ Surgical history } \\
\hline Parathyroidectomy & $4(4.3 \%)$ \\
\hline Heart operation & $7(7.6 \%)$ \\
\hline Kidney transplantation & $9(9.8 \%)$ \\
\hline Solid organ transplantation ${ }^{b}$ & $3(3.3 \%)$ \\
\hline
\end{tabular}

Values are given as number (\%) or mean \pm standard deviation

${ }^{\mathrm{a}}$ Gastrointestinal tract bleeding, hemoptysis. ${ }^{\mathrm{b}}$ Other than the kidneys $\mathrm{DM}$, diabetes mellitus; HD, hemodialysis; HTN, hypertension; GN, glomerulonephropathy; ADPKD, autosomal dominant polycystic kidney disease; CVD, cardiovascular disease; $C H F$, congestive heart failure; $V H D$, valvular heart disease; CAOD, coronary artery occlusive disease; PAOD, peripheral artery occlusive disease; CVA, cerebrovascular accident

measurement day $(p=0.125)$. There was also no significant change in the number of patients with $\mathrm{Hb}$ levels of $>10 \mathrm{~g} / \mathrm{dL}(p=0.100)$. A significantly higher dose of ESA was administrated to patients with lower Hb levels $(p<0.001)$. 
Table $2 \mathrm{Hb}$ levels, ESA and IV iron doses, anemia- and volume status-related parameters

\begin{tabular}{|c|c|c|c|}
\hline & Early-week days & Mid-week days & $P$-value \\
\hline $\mathrm{Hb}(\mathrm{g} / \mathrm{dL})$ & $10.71 \pm 0.06$ & $10.78 \pm 0.47$ & 0.105 \\
\hline Hct (\%) & $33.83 \pm 12.36$ & $32.36 \pm 1.53$ & 0.230 \\
\hline Dose of ESA ( $\mu \mathrm{g} / \mathrm{month})^{\text {a }}$ & $175.4 \pm 72.5$ & $163.7 \pm 83.6$ & 0.022 \\
\hline Median (range) & $170.0(0-376.7)$ & $157.1(13.3-492.5)$ & \\
\hline Interquartile range & $123.5-201.9$ & $108.0-208.8$ & \\
\hline Dose of IV iron (mg/year) ${ }^{b}$ & $623.0 \pm 489.0$ & $447.0 \pm 505.2$ & 0.001 \\
\hline \multicolumn{4}{|l|}{ Parameters related to volume status } \\
\hline Interdialytic body weight gain (kg) & $2.81 \pm 0.82$ & $1.99 \pm 0.61$ & $<0.001$ \\
\hline Ultrafiltration volume (kg) & $2.65 \pm 0.73$ & $2.12 \pm 0.66$ & $<0.001$ \\
\hline Pre-dialysis body weight/DBW (\%) & $104.89 \pm 3.42$ & $103.51 \pm 1.77$ & $<0.001$ \\
\hline \multicolumn{4}{|l|}{ Parameters related to anemia } \\
\hline spKt $/ N$ & $1.63 \pm 0.24$ & $1.67 \pm 0.23$ & $<0.001$ \\
\hline Albumin (g/dL) & $3.62 \pm 0.74$ & $3.76 \pm 0.80$ & $<0.001$ \\
\hline Prealbumin (mg/dL) & $34.05 \pm 7.01$ & $31.94 \pm 6.84$ & $<0.001$ \\
\hline hs-CRP (mg/L) & $0.26 \pm 0.33$ & $0.28 \pm 0.33$ & 0.151 \\
\hline Ferritin $(\mathrm{ng} / \mathrm{mL})$ & $386.0 \pm 292.4$ & $308.1 \pm 238.0$ & $<0.001$ \\
\hline TSAT (\%) & $36.43 \pm 9.03$ & $37.46 \pm 10.90$ & 0.304 \\
\hline iPTH (pg/mL) & $205.1 \pm 113.7$ & $230.4 \pm 129.9$ & 0.021 \\
\hline
\end{tabular}

Values are given as mean \pm standard deviation unless otherwise indicated

${ }^{a}$ darbepoetin alfa. ${ }^{\mathrm{b}}$ iron hydroxide sucrose

$\mathrm{Hb}$, hemoglobin; Hct, hematocrit; ESA, erythropoiesis-stimulating agent; IV, intravenous; DBW, dry body weight; spKt/V, single pool Kt/V; hs-CRP, high-sensitivity Creactive protein; TSAT, transferrin saturation; $\mathrm{PPTH}$, intact parathyroid hormone

\section{Discussion}

The present study revealed that mid-week measurements were associated with lower doses of ESA and IV iron, without a difference in $\mathrm{Hb}$ levels. The interdialytic weight gain was lower when the measurements were performed on mid-week days. Moreover, there was no significant difference in the number of patients with $\mathrm{Hb}$ levels of $>10.0 \mathrm{~g} / \mathrm{dL}$, and higher doses of ESA were administered to patients with $\mathrm{Hb}$ levels of $<10.0 \mathrm{~g} / \mathrm{dL}$ than to those with $\mathrm{Hb}$ levels of $>10.0 \mathrm{~g} / \mathrm{dL}$. It appears that

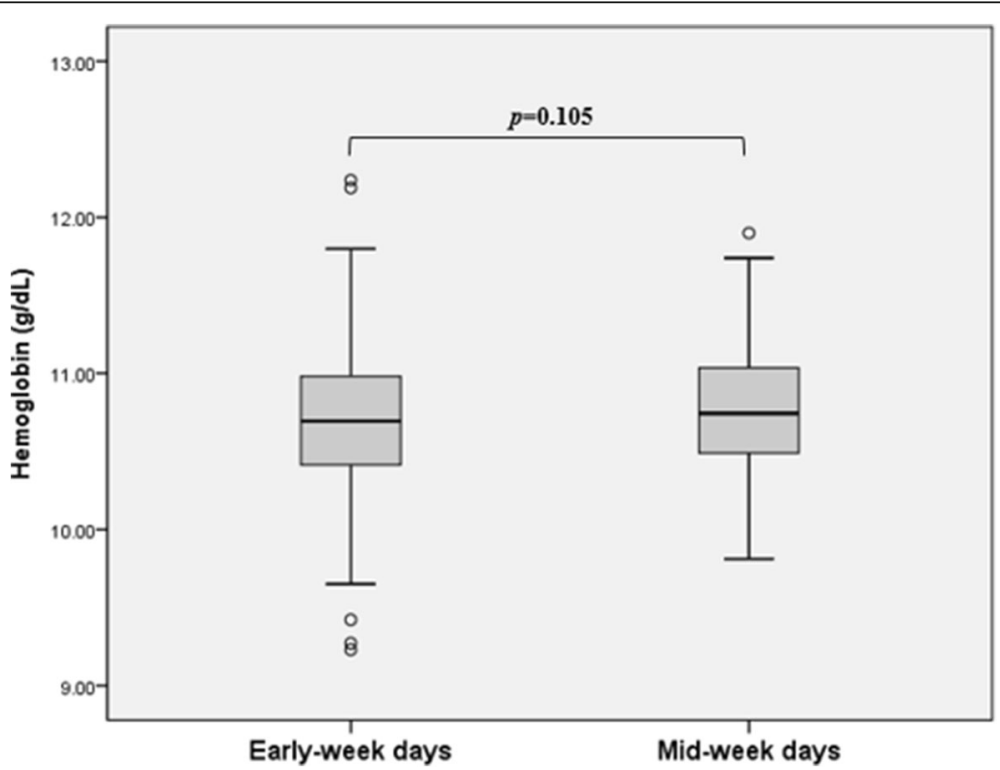

Fig. 1 Hemoglobin levels according to hemoglobin measurement day. There was no significant difference in the mean hemoglobin levels between the early-week and mid-week measurements 


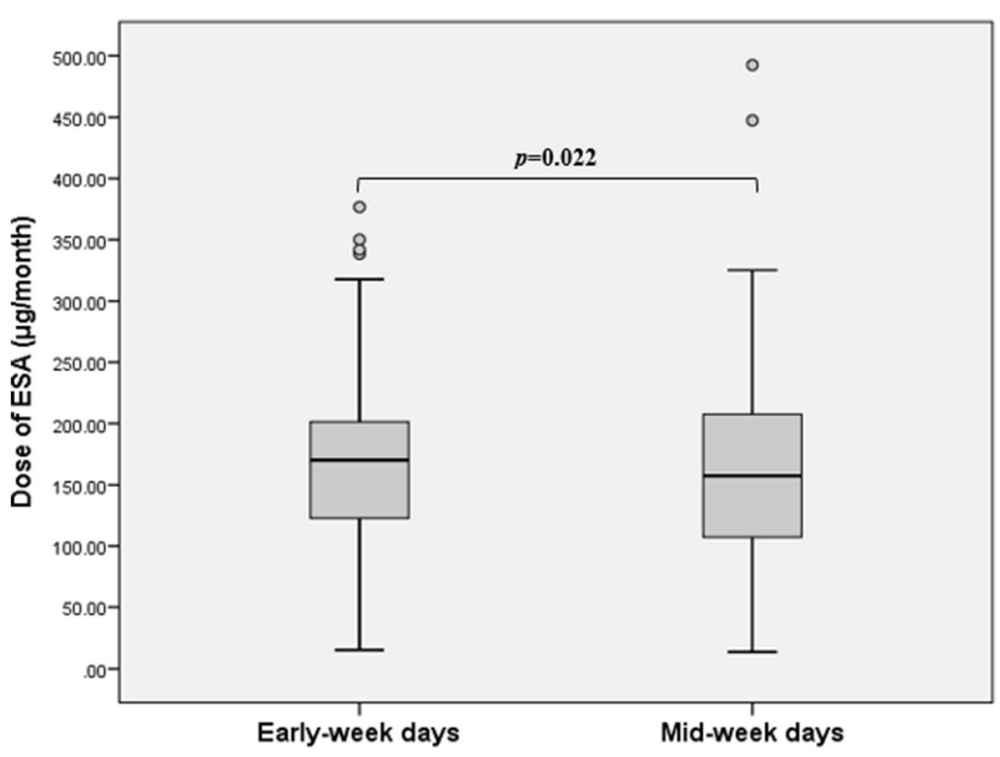

Fig. 2 Mean doses of erythropoiesis-stimulating agents before and after changing the hemoglobin measurement day. The mean dose of darbepoetin-a alfa was significantly higher for early-week days than for mid-week days. ESA, erythropoiesis-stimulating agent

this is the first study to suggest that different doses of ESA may be required based on the day of $\mathrm{Hb}$ measurement in clinical practice.

Because short-term $\mathrm{Hb}$ variability can be affected by volume status, the measured pre-dialysis $\mathrm{Hb}$ levels are higher on mid-week days than on early-week days in HD patients [21]. However, the present study did not reveal a difference in the $\mathrm{Hb}$ levels according to the measurement day, although there was a significant difference in the ESA doses. It is possible that changing the $\mathrm{Hb}$ measurement day resulted in lower prescribed ESA doses, rather than higher measured $\mathrm{Hb}$ levels, because of the reimbursement system in South Korea. In this context, the public medical insurance system covers ESA treatment for CKD anemia up to $\mathrm{Hb}$ levels of $11.0 \mathrm{~g} / \mathrm{dL}$ $[29,30]$. In the present study, the median ESA dose before September 2013 was similar to the data from the Korean Clinical Research Center for ESRD (CRC-ESRD), which suggests that mid-week pre-dialysis $\mathrm{Hb}$ measurements could result in lower prescribed ESA doses. In

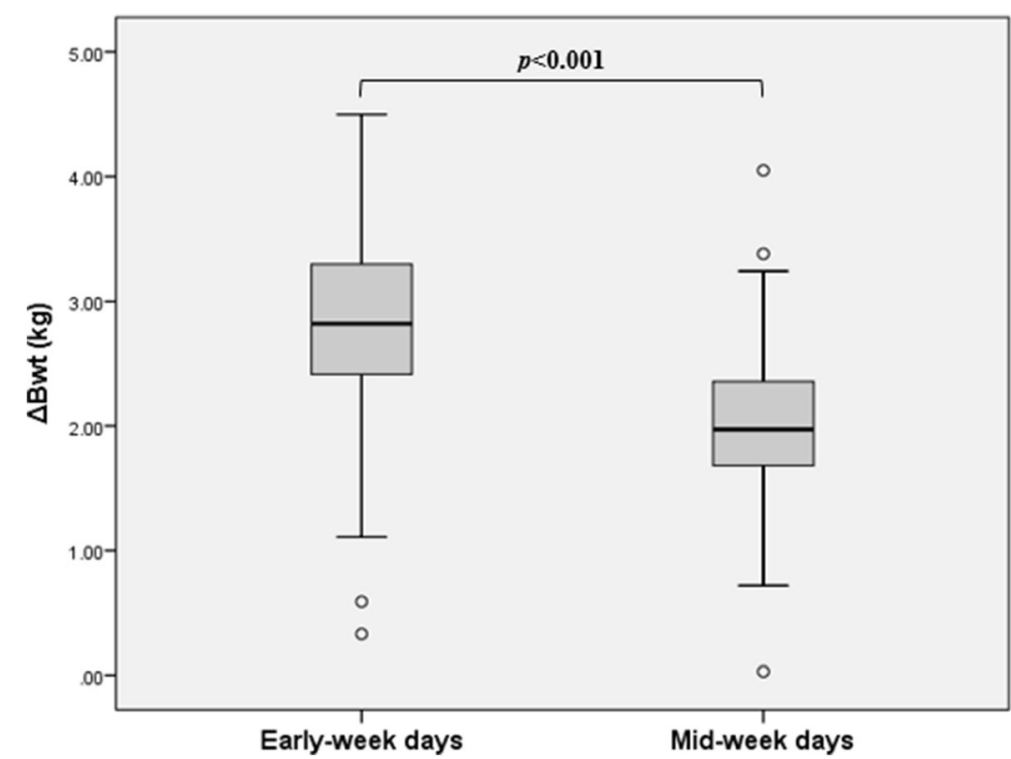

Fig. 3 Interdialytic body weight gains according to hemoglobin measurement day. There was a significant difference in the mean interdialytic weight gains between the early-week and mid-week measurements. $\Delta$ Bwt, interdialytic body weight gain 
Table 3 Dose of ESA according to Hb level

\begin{tabular}{|c|c|c|c|c|}
\hline & $\mathrm{Hb}$ of $<10 \mathrm{~g} / \mathrm{dL}$ & $\mathrm{Hb}$ of $10-11 \mathrm{~g} / \mathrm{dL}$ & $\mathrm{Hb}$ of $\geq 11 \mathrm{~g} / \mathrm{dL}$ & $P$-value \\
\hline \multicolumn{5}{|l|}{ Early-week days } \\
\hline Number of patients & 8 & 64 & 20 & \\
\hline $\mathrm{Hb}(\mathrm{g} / \mathrm{dL})$ & $9.71(9.23-9.97)$ & 10.63 (10.03-10.99) & $11.45(11.01-12.24)$ & \\
\hline ESA ( $\mu \mathrm{g} /$ month) & 311.67 (188.33-376.67) & 179.17 (89.17-317.50) & $93.34(0-255.83)$ & $<0.001$ \\
\hline \multicolumn{5}{|l|}{ Mid-week days } \\
\hline Number of patients & 2 & 65 & 25 & \\
\hline $\mathrm{Hb}(\mathrm{g} / \mathrm{dL})$ & 9.88 (9.81-9.94) & $10.61(10.03-10.97)$ & $11.22(11.0-12.87)$ & \\
\hline $\mathrm{ESA}$ ( $\mu \mathrm{g} / \mathrm{month})$ & $292.5(260-325)$ & 183.33 (69.17-492.50) & $95(13.33-233.33)$ & $<0.001$ \\
\hline$P$-value ${ }^{b}$ & $p=0.125^{\mathrm{a}}\left(p=0.100^{\mathrm{b}}\right)$ & & & \\
\hline
\end{tabular}

Values are given as number or median (range)

${ }^{a}$ Comparing the number of patients for early-week days and mid-week days. ${ }^{\mathrm{b}}$ Comparing the number of patients with $\mathrm{Hb}$ levels of $>10.0 \mathrm{~g} / \mathrm{dL}$ $\mathrm{Hb}$, hemoglobin; ESA, erythropoiesis-stimulating agent

addition, patients with lower $\mathrm{Hb}$ levels received higher ESA doses in the present study, which reflects target-based ESA dosing because patients with ESA hypo-responsiveness require a higher ESA dose to achieve their target $\mathrm{Hb}$ level. This trend has also been observed during the secondary analysis of data from randomized controlled trials (i.e., the CHOIR and TREAT trials) [13, 14].

Because of short-term $\mathrm{Hb}$ variability, several discussions addressed the estimation of a representative $\mathrm{Hb}$ level in ESRD patients receiving HD [21, 24, 26]. Bellizzi et al. first recommended identifying anemia based on the pre-dialysis $\mathrm{Hb}$ level after a short interdialytic period (i.e., mid-week days) [21]. Krisper et al. proposed using the $\mathrm{Hb}$ time-averaged concentration (Hb-tac) and developed a formula to calculate $\mathrm{Hb}$-tac using the pre- and post-dialysis $\mathrm{Hb}$ levels [24]. Other studies estimated the required dose of ESA based on values other than the pre-dialysis $\mathrm{Hb}$ level $[25,26]$. Siga et al. reported that the estimated ESA doses based on Hb-tac or the average of pre- and post-dialysis $\mathrm{Hb}$ levels were significantly lower than the dose estimated based on the mid-week pre-dialysis $\mathrm{Hb}$ level [26]. Castillo et al. also reported a significantly lower estimated ESA dose based on the post-dialysis $\mathrm{Hb}$ level [25]. These findings suggest that the recommended ESA dose can vary according to the timing and/or method for determining the representative $\mathrm{Hb}$ level in HD patients.

The published guidelines for CKD anemia do not definitively address $\mathrm{Hb}$ measurement days and target $\mathrm{Hb}$ levels for ESA therapy. Based on varying levels of evidence, most Western guidelines prefer mid-week predialysis sampling for $\mathrm{Hb}$ measurement, with a target $\mathrm{Hb}$ range of $11.0-12.0 \mathrm{~g} / \mathrm{dL}$, regardless of renal replacement therapy modality. For example, the KDOQI guidelines recommended an $\mathrm{Hb}$ target of $11.0-12.0 \mathrm{~g} / \mathrm{dL}$ and mentioned that mid-week pre-dialysis sampling is theoretically optimal, although they acknowledge that pre-dialysis sampling can be performed without a preference for specific days of the week, based on a lack of data regarding patient outcomes according to sampling timing [1, 17]. The KDIGO guidelines also generally recommended an $\mathrm{Hb}$ target of $11.5 \mathrm{~g} / \mathrm{dL}$ and mentioned that $\mathrm{Hb}$ monitoring is traditionally performed before a mid-week HD session to minimize $\mathrm{Hb}$ variability, although they acknowledge that the mid-week timing is not essential [18]. The Canadian Society of Nephrology guidelines also recommended an $\mathrm{Hb}$ target of $11.0 \mathrm{~g} / \mathrm{dL}$ and indicated that mid-week pre-dialysis $\mathrm{Hb}$ measurement is preferable because of $\mathrm{Hb}$ variability and a lack of association between post-dialysis $\mathrm{Hb}$ levels and clinical outcomes (Grade D recommendation) [27, 31]. In contrast, the Japanese Society for Dialysis Therapy (JSDT) guidelines recommended pre-dialysis $\mathrm{Hb}$ measurement at the beginning of the week (2 days from the last dialysis session) with an $\mathrm{Hb}$ target of 10.0-11.0 g/dL (moderately strong recommendation). The JSDT recommendation is based on the prevalent Japanese practice of blood sampling at the beginning of the week, as well as studies regarding the survival of Japanese maintenance HD patients by Hirasawa et al. and the JSDT. In a recent study by the Korean CRC-ESRD, Hb levels of 10.0-11.0 $\mathrm{g} / \mathrm{dL}$ were found to provide a survival benefit among Korean HD patients, although that study did not consider the day or timing of the $\mathrm{Hb}$ measurement. Furthermore, the Korean CRC-ESRD study revealed that patients with $\mathrm{Hb}$ levels of $\geq 10.0 \mathrm{~g} / \mathrm{dL}$ and a median ESA dose of $<126 \mu \mathrm{g} / \mathrm{week} / \mathrm{kg}$ had the best survival probability [29].

In the present study, a lower ESA dose was observed after the change in the day of the $\mathrm{Hb}$ measurement. From the perspective of $\mathrm{Hb}$ variability, a change in the $\mathrm{Hb}$ measurement day might actually result in a decreased target $\mathrm{Hb}$ level. Given the price of $\mathrm{Nesp}^{\circ}$ (about $\$ 17.3$ per $20 \mathrm{mcg}$ prefilled syringe in South Korea, April 2019), the number of ESRD patients in 
South Korea in the year of 2017 (73059), and the approximate difference of darbepoetin alpha in our study (10 mcg / month/person), the cost difference would be at least \$ 7 million a year in South Korea. Considering the huge cost and that the administered ESA dose and the achieved $\mathrm{Hb}$ level both are critical prognostic factors, it is important to properly determine the representative $\mathrm{Hb}$ level in ESRD patients receiving $\mathrm{HD}$. Because anemia in ESRD patients can cause poor outcomes, including shortened survival, ESA dosing based on early-week $\mathrm{Hb}$ measurements may be desirable. However, because of the short-term variability in $\mathrm{Hb}$ levels, ESA dosing based on mid-week $\mathrm{Hb}$ measurements with a higher target $\mathrm{Hb}$ level may be more accurate. Moreover, considering the complications and poor prognosis related to a higher ESA dose and/or ESA hypo-responsiveness, ESA dosing based on midweek $\mathrm{Hb}$ measurement with the current $\mathrm{Hb}$ target level may be an effective approach. Therefore, a clinical trial with pre-dialysis $\mathrm{Hb}$ measurement on midweek days is likely needed to precisely identify the target $\mathrm{Hb}$ level needed to improve the prognosis of $\mathrm{HD}$ patients. Future studies should also consider patient ethnicity, given that there are ethnic differences in $\mathrm{Hb}$ levels.

The present study has some limitations. First, sample size is small considering the small difference of ESA dose before and after the change of $\mathrm{Hb}$ measurement day. Despite the small sample size, considering the scarcity of study about $\mathrm{Hb}$ measurement day in clinical practice and the large number of ESRD patients and burden worldwide, we think this study is still meaningful. Future studies about CKD anemia should take account of the $\mathrm{Hb}$ measurement day. Second, there are several study design limitations, such as selection bias, information bias and confounding. The physicians who prescribed the ESA were changed annually in our center, which suggests that inter-individual differences in ESA dosing practice could have influenced the results. Third, the study did not evaluate clinical outcomes related to the ESA dose. Echocardiographic parameters such as left ventricular ejection fraction, left ventricular mass index would be important parameters related to the outcomes, but only few patients underwent echocardiography twice during the study period.

\section{Conclusion}

In conclusion, relative to early-week measurements, mid-week pre-dialysis $\mathrm{Hb}$ measurements were significantly associated with lower doses of ESA and IV iron to maintain the target $\mathrm{Hb}$ level in ESRD patients receiving $\mathrm{HD}$. Thus, mid-week $\mathrm{Hb}$ measurements would be a better criterion for determining the appropriate ESA dose.

\section{Abbreviations}

CKD: Chronic kidney disease; CRC-ESRD: The Korean clinical research center for end stage renal disease; CVA: Cerebrovascular accident; CVD: Cardiovascular disease; EPO: Erythropoietin; ESA: Erythropoiesisstimulating agent; ESRD: End stage renal disease; Hb: Hemoglobin; Hct: Hematocrit; HD: Hemodialysis; IV: Intravenous; JSDT: Japanese Society for Dialysis Therapy; KDIGO: The Kidney Disease Improving Global Outcomes; KDOQI: The National Kidney Foundation Kidney Disease Outcomes Quality Initiative; rhEPO: Recombinant human erythropoietin; RRT: Renal replacement therapy

\section{Acknowledgements \\ Not applicable.}

\section{Authors' contributions}

SYB contributed to the design of the study, the acquisition, analysis and interpretation of data, and to the writing of the manuscript. JWJ and SHK contributed to the acquisition and analysis of data. CHB, JWJ, WSY, SBK, and SKL substantively revised the draft. SKP initially suggested the conception of the study and revised the draft. HK contributed to the design of the study, analysis and interpretation of data, and to the writing and revision of the draft. All authors have approved the final version and agreed to be accountable for the author's own contributions.

\section{Funding}

Not applicable.

\section{Availability of data and materials}

The datasets used and/or analyzed during the current study are available from the corresponding author on reasonable request.

\section{Ethics approval and consent to participate}

The study was approved by the institutional review board of Asan Medical Center. Informed consent was not required, given the retrospective observational study design.

\section{Consent for publication}

Not applicable.

\section{Competing interests}

The authors declare that they have no competing interests.

\section{Author details}

'Department of Internal Medicine, Busan Bumin Hospital, Busan, Republic of Korea. ${ }^{2}$ Division of Nephrology, Department of Internal Medicine, College of Medicine, Chungnam National University Hospital, Daejeon, Republic of Korea. ${ }^{3}$ Department of Internal Medicine, Asan Medical Center, University of Ulsan College of Medicine, Seoul, Republic of Korea. ${ }^{4}$ Division of Nephrology, Department of Internal Medicine, Asan Medical Center, University of Ulsan College of Medicine, 88, Olympic-ro 43-gil, Songpa-gu, Seoul 05505, Republic of Korea.

Received: 18 March 2019 Accepted: 25 July 2019

Published online: 02 August 2019

\section{References}

1. KDOQI; National Kidney Foundation. KDOQI clinical practice guidelines and clinical practice recommendations for anemia in chronic kidney disease. Am J Kidney Dis. 2006;47:S11.

2. Babitt JL, Lin HY. Mechanisms of anemia in chronic kidney disease. J Am Soc Nephrol. 2012;23:1631-4.

3. Winearls CG, Oliver DO, Pippard MJ, Reid C, Downing MR, Cotes PM. Effect of human erythropoietin derived from recombinant DNA on the anaemia of patients maintained by chronic haemodialysis. Lancet. 1986;2:1175-8.

4. Eschbach JW, Egrie JC, Downing MR, Browne JK, Adamson JW. Correction of the anemia of end-stage renal disease with recombinant human erythropoietin. Results of a combined phase I and II clinical trial. N Engl J Med. 1987;316:73-8.

5. Drueke TB, Locatelli F, Clyne N, Eckardt KU, Macdougall IC, Tsakiris D, et al. Normalization of hemoglobin level in patients with chronic kidney disease and anemia. N Engl J Med. 2006;355:2071-84. 
6. Besarab A, Goodkin DA, Nissenson AR. Normal hematocrit cardiac trial a. the normal hematocrit study--follow-up. N Engl J Med. 2008;358:433-4.

7. Singh AK, Szczech L, Tang KL, Barnhart H, Sapp S, Wolfson M, et al. Correction of anemia with epoetin alfa in chronic kidney disease. N Engl J Med. 2006;355:2085-98.

8. Skali H, Parving HH, Parfrey PS, Burdmann EA, Lewis EF, Ivanovich $P$, et al. Stroke in patients with type 2 diabetes mellitus, chronic kidney disease, and anemia treated with Darbepoetin alfa: the trial to reduce cardiovascular events with Aranesp therapy (TREAT) experience. Circulation. 2011;124: 2903-8.

9. Besarab A, Bolton WK, Browne JK, Egrie JC, Nissenson AR, Okamoto DM, et al. The effects of normal as compared with low hematocrit values in patients with cardiac disease who are receiving hemodialysis and epoetin. N Engl J Med. 1998;339:584-90.

10. Pfeffer MA, Burdmann EA, Chen CY, Cooper ME, de Zeeuw D, Eckardt KU, et al. A trial of darbepoetin alfa in type 2 diabetes and chronic kidney disease. N Engl J Med. 2009;361:2019-32.

11. Locatelli F, Aljama P, Canaud B, Covic A, De Francisco A, Macdougall IC, et al. Target haemoglobin to aim for with erythropoiesis-stimulating agents: a position statement by ERBP following publication of the trial to reduce cardiovascular events with Aranesp therapy (TREAT) study. Nephrol Dial Transplant. 2010;25:2846-50.

12. Regidor DL, Kopple JD, Kovesdy CP, Kilpatrick RD, McAllister CJ, Aronovitz J, et al. Associations between changes in hemoglobin and administered erythropoiesis-stimulating agent and survival in hemodialysis patients. J Am Soc Nephrol. 2006:17:1181-91.

13. Solomon SD, Uno H, Lewis EF, Eckardt KU, Lin J, Burdmann EA, et al. Erythropoietic response and outcomes in kidney disease and type 2 diabetes. N Engl J Med. 2010;363:1146-55.

14. Szczech LA, Barnhart HX, Inrig JK, Reddan DN, Sapp S, Califf RM, et al. Secondary analysis of the correction of hemoglobin in the outcomes in renal insufficiency (CHOIR) trial epoetin-alpha dose and achieved hemoglobin outcomes. Kidney Int. 2008;74:791-8.

15. Zhang Y, Thamer M, Stefanik K, Kaufman J, Cotter DJ. Epoetin requirements predict mortality in hemodialysis patients. Am J Kidney Dis. 2004;44:866-76.

16. Kainz A, Mayer B, Kramar R, Oberbauer R. Association of ESA hyporesponsiveness and haemoglobin variability with mortality in haemodialysis patients. Nephrol Dial Transplant. 2010;25:3701-6.

17. KDOQI. KDOQI clinical practice guideline and clinical practice recommendations for anemia in chronic kidney disease: 2007 update of hemoglobin target. Am J Kidney Dis. 2007;50:471-530.

18. Kidney Disease: Improving Global Outcomes Anemia Work Group. KDIGO clinical practice guideline for anemia in chronic kidney disease. Kidney Int Suppl. 2012;2:279-335.

19. Kalantar-Zadeh K, Aronoff GR. Hemoglobin variability in anemia of chronic kidney disease. J Am Soc Nephrol. 2009;20:479-87.

20. Fishbane S, Berns JS. Evidence and implications of haemoglobin cycling in anaemia management. Nephrol Dial Transplant. 2007;22:2129-32.

21. Bellizzi $V$, Minutolo $R$, Terracciano V, lodice C, Giannattasio P, De Nicola L, et al. Influence of the cyclic variation of hydration status on hemoglobin levels in hemodialysis patients. Am J Kidney Dis. 2002;40:549-55.

22. Movilli E, Cancarini GC, Cassamali S, Camerini C, Brunori G, Maffei C, et al. Inter-dialytic variations in blood volume and total body water in uraemic patients treated by dialysis. Nephrol Dial Transplant. 2004;19:185-9.

23. Minutolo R, De Nicola L, Bellizzi V, lodice C, Rubino R, Aucella F, et al. Intraand post-dialytic changes of haemoglobin concentrations in non-anaemic haemodialysis patients. Nephrol Dial Transplant. 2003;18:2606-12.

24. Krisper P, Quehenberger F, Schneditz D, Holzer H, Polaschegg HD. Prediction of time-averaged concentration of haemoglobin in haemodialysis patients. Nephrol Dial Transplant. 2003;18:2082-7.

25. Castillo N, Garcia-Garcia P, Rivero A, Jimenez-Sosa A, Macia M, Getino $M A$, et al. Should we adjust erythropoiesis-stimulating agent dosage to postdialysis hemoglobin levels? A pilot study. BMC Nephrol. 2012;13:60.

26. Siga E, Fernandez M, Galarza M, Mesina V, De Palma H, Coste R. Difference between true functional haemoglobin and pre-dialysis haemoglobin is associated with plasma volume variation: a multicentre study. Int Urol Nephrol. 2014;46:2379-84.

27. White CT, Barrett BJ, Madore F, Moist LM, Klarenbach SW, Foley RN, et al. Clinical practice guidelines for evaluation of anemia. Kidney Int Suppl. 2008; 74(supplement 110):S4-6.
28. Tsubakihara Y, Nishi S, Akiba T, Hirakata H, Iseki K, Kubota M, et al. 2008 Japanese Society for Dialysis Therapy: guidelines for renal anemia in chronic kidney disease. Ther Apher Dial. 2010;14:240-75.

29. Kwon O, Jang HM, Jung HY, Kim YS, Kang SW, Yang CW, et al. The Korean clinical research center for end-stage renal disease study validates the association of hemoglobin and erythropoiesis-stimulating agent dose with mortality in hemodialysis patients. PLoS One. 2015;10:e0140241.

30. Jin DC, Yun SR, Lee SW, Han SW, Kim W, Park J, et al. Lessons from 30 years' data of Korean end-stage renal disease registry, 1985-2015. Kidney Res Clin Pract. 2015;34:132-9.

31. Moist LM, Foley RN, Barrett BJ, Madore F, White CT, Klarenbach SW, et al. Clinical practice guidelines for evidence-based use of erythropoieticstimulating agents. Kidney Int Suppl. 2008;74:S12-8.

\section{Publisher's Note}

Springer Nature remains neutral with regard to jurisdictional claims in published maps and institutional affiliations.

Ready to submit your research? Choose BMC and benefit from:

- fast, convenient online submission

- thorough peer review by experienced researchers in your field

- rapid publication on acceptance

- support for research data, including large and complex data types

- gold Open Access which fosters wider collaboration and increased citations

- maximum visibility for your research: over $100 \mathrm{M}$ website views per year

At BMC, research is always in progress.

Learn more biomedcentral.com/submissions 